\title{
広島県の観光地に対する心理的評価に関する研究
}

\author{
日本人学生と中国人学生による画像評価と実空間評価の比較
}

\section{A STUDY ON THE PSYCHOLOGICAL EVALUATION OF TOURIST SPOTS IN HIROSHIMA}

Comparison of the results of image-based evaluation and onsite evaluation between Japanese and Chinese students

\author{
石川瑞穂 ${ }^{* 1}$, 西名大作 ${ }^{2}$, 金華*3, 陸偉*4, \\ 田中貴宏*2, 吉原 俊 朗*5, 劉娜*6 \\ Mizuho ISHIKAWA, Daisaku NISHINA, Hua JIN, Wei LU, \\ Takahiro TANAKA, Toshiro YOSHIHARA and Liu NA
}

\begin{abstract}
In this study, we compared the results of psychological evaluation of tourist spots in Hiroshima obtained by image-based and onsite experiments using Chinese and Japanese subjects as nonresidents and residents.

As a common tendency, in actually visit, the way of thinking and feeling of the individual became clearly by the increase of the information. For the Chinese, it can be said that they were interested in what they perceived as special regardless whether it was Japanese or not Japanese before visit. However, after visit, they became to be interested in Japanese traditional elements, because they understood likeness of Japan.
\end{abstract}

Keywords : Sightseeing scene, Psychological evaluation, Chinese subjects, Japanese subjects, Tourist spots 観光景観, 心理評価実験, 中国人被験者, 日本人被験者, 観光地

\section{1. はじめに}

人口減少時代である近年，観光業は地方都市の活性化や生活の質 向上のための重要な柱となっている。日本は自然や文化など豊富な 観光資源を有しており, それらの活用が地方創生一の切り札として 期待が寄せられている。特に, 地域の持続的な発展に向けて観光地 づくりとまちづくりを一体的に行う観光まちづくりが注目されてい るなど，まちづくりにおける観光の役割が重要視されている。国土 交通省発行の観光まちづくりガイドラインで設けた，自治体が取り 組む際に考慮する事項の一つとして, 外からの視点という着眼点が ある。ここでは, 長年その地域に住んでいる居住者よりも, 外の人, つまり非居住者のほうが地域の価值を見つけることに長けていると され, 非居住者が魅力的と思う観光資源を発見することが観光まち づくりの第一歩として位置づけられている。

一方，現在，社会はグローバル化がますます進んでおり，世界各 国との関係性は国家間のみでなく個人間でも密なものとなりつつあ る。インターネットや SNS の普及などから世界中の情報を数多く 入手寸ることができ，海外諸国がより身近な存在となっている。日 本の歴史や文化も伝統的なものからサブカルチャーまで幅広く注目
され親しまれており，日本を訪れる外国人も増加傾向にあり，2016 年には訪日外国人観光客数は初めて 2000 万人を突破し，その後も その勢いは止まらず，各月の過去の記録を更新し続けている 1)。東 京オリンピックの開催などから，今後も増加の一途をたどると予想 される。こうした状況から, 今後の観光業の発展のためには, 外国 人観光客の視点が不可欠であり, 観光まちづくりの上でも, 非居住 者にとって魅力的な観光資源を発見するにあたって，日本の観光地 に対する外国人観光客の捉え方を把握することが重要であると考え られる。

これまで居住者と非居住者の両側から観光地を評価, 考察した研 究は多く行われている。直井ら 2)は, 岐阜県高山市を対象に, 訪問 客が訪れる空間と居住空間が重複する歴史的町並みにおいて, 訪問 客がまなざしを向ける地元の生活の様相を明らかにし, 地元の生活 が観光資源となる可能性を示した。また，白ら ${ }^{3)}$ は，韓国のドンピ ラン地域を対象に, 住民の意識と観光客の観光動態と評価を調查し, 観光客に魅力のある観光まちづくり活動のためには住民との交流や まちの案内など多様な形で行う必要があることを示し, 住民参加に よる観光まちづくりの利点と課題を明らかにした。しかしながら，
*1 (株東畑建築事務所 修士 (工学)

*2 広島大学大学院工学研究科 教授 $\cdot$ 博士 (工学)

*3 大連民族大学設計学院 教授・博士 (工学)

*4 大連理工大学建築芸術学院 教授・修士 (工学)

*5 (公財) 中国地域創造研究センター 博士 (工学)

*6 広島大学大学院工学研究科 博士後期課程 $/$ 常州軽工職業技術学院 講師
Tohata Architects \& Engineers, M.Eng.

Prof., Graduate School of Eng., Hiroshima Univ., Dr.Eng.

Prof., Design College, Dalian Minzu Univ., Dr.Eng.

Prof., School of Architecture and Fine Art, Dalian Univ. of Technology, M.Eng.

Chugoku Regional Innovation Research Center, Dr.Eng.

Grad. Student, Graduate School of Eng., Hiroshima Univ.

Lect., Changzhou Vocational Institute of Light Industry 
両研究は対象とする非居住者を国内の観光客に限定しており, 外国 人観光客に対する知見は得られていない。

一方で，外国人観光客に着目し観光地を評価した研究も多く行わ れている。山口ら ${ }^{4)}$ は, 山形県庄内地域を対象に, 韓国人, 中国人, 台湾人観光客に対して, 旅行の満足度の評価を求め, 訪日経験が観 光地の評価に影響を及ぼす傾向を明らかにした。また, 本論文の先 行研究としても位置付けられる高岸ら5の研究では, 中国人一般市 民と学生を被験者として, 広島県の観光景観画像を用いて心理的評 価実験を行い, 両者の認識構造の相違を明らかにし, 日本的特徵に ついての認識が観光景観に対する認識構造に影響を及ぼすことを示 した。しかしながらこれらの研究は観光地を訪問する前の段階, も しくは訪問後の段階での調査に留まっている。

一般に観光行動は, 訪問先を決定するための事前情報を獲得した 後, 実際に訪問するという連続的なプロセスを経ている。したがっ て観光地において, 訪問前の事前情報による印象と訪問後の実空間 における印象は, 同一の観光行動の中で評価される必要性があると 考えられる。特に, 訪問前後での観光客の観光地に対する印象の変 化を把握することは, 口コミによる新規訪問客の誘致やリピーター の確保につながる魅力的な観光資源発見のための新たな知見となる 可能性が考えられる。

観光客の訪問前後での印象を調査している研究としては, 野瀬ら 6)や大久保ら 7)の研究が挙げられる。前者は日光, 箱根を対象として, 事前期待と満足感それぞれに対して日本人，外国人観光客の比較検 討を行っているが, 両者の関係性については言及していない。後者 は外国人観光客の訪日前の期待を形成寸る情報源として旅行ガイド ブックを, 訪問後の評価として旅行ロコミサイトの投稿を用いて言 語比較分析を行い, 両者の特徵の差異を把握しているが, 同一被験 者の一連の観光行動には着目しておらず，訪問前後における外国人 観光客の認識構造の変化に関しては把握していない。

以上より, 本研究では「非居住者として外国人観光客の日本の観 光地に対する捉え方を把握する」「訪問前後で一連の観光行動として 観光地の印象を把握する」という 2 つの観点から, 広島県の観光地 に対して, 非居住者である外国人観光客による, 訪問前の事前情報 による印象と, 訪問後の実空間による印象の差異を明らかにするこ とを目的とする注 1)。

対象とする外国人観光客は中国人注 2) とする。2010 年のビザ発給 要件の大幅な緩和措置を発端に, 中国からの訪日観光客の増加は著 しく，今後も増加が見込まれると予想される。しかしながらその訪 問先は東京都や大阪府などの大都市に集中しており, 各国の都道府 県別訪問率ランキング 8)によると, 広島県はイギリスとアメリカで は 6 位である一方, 中国では 20 位であり, 欧米諸国に比べて中国 からの訪問数は少ないと言える。従って, 中国人観光客の意識を解 明することは，広島県を始めとする地方都市一の観光客誘致におい て重要な課題であると考えられる。

また, 本研究で得られる成果が非居住者である中国人の特徵的な ものであることを把握するために，居住者としての位置づけのもと で日本人に対しても同様の調查を実施し, 比較することとした。本 研究における居住者と非居住者の違いは, その土地の文化や歴史一 の理解及び観光地に対する訪問経験から生じるものと考え, 居住者 としての日本人の定義を一定期間以上広島県内で暮らしている者,

\section{Table1 Explanatory texts}

\begin{tabular}{|c|c|}
\hline \multirow{3}{*}{$\begin{array}{l}\text { Itsukushima Shrine } \\
\text { 撖島神社 }\end{array}$} & $\begin{array}{l}\text { (1) It is a shrine one of Japan's three scenic spots, and that is } \\
\text { registered as a World Heritage Site. }\end{array}$ \\
\hline & $\begin{array}{l}\text { (2) In neighboring shops, you can eat regional specialties such as } \\
\text { rice dish and oyster dish. }\end{array}$ \\
\hline & $\begin{array}{l}\text { (3)Fireworks festival is held every August, and fireworks are } \\
\text { launched at the sea behind Otorii. }\end{array}$ \\
\hline \multirow{3}{*}{$\begin{array}{l}\text { Shukkeien } \\
\text { 縮景園 }\end{array}$} & $\begin{array}{l}\text { (1) It is a Japanese garden made in the 17th century simulating } \\
\text { "West Lake" in China. }\end{array}$ \\
\hline & $\begin{array}{l}\text { (2) A tea ceremony where you can enjoy Japanese tea (Matcha) is } \\
\text { held every season. }\end{array}$ \\
\hline & $\begin{array}{l}\text { (3) It is one of the scenic spots (cultural properties) designated by } \\
\text { gavament. }\end{array}$ \\
\hline \multirow{3}{*}{$\begin{array}{l}\text { Peace museum } \\
\text { 平和記念資料館 }\end{array}$} & (1) It is a museum designed by Kenzo Tange. \\
\hline & $\begin{array}{l}\text { (2) You can learn the damage from atomic bombs and the } \\
\text { importance of world peace. }\end{array}$ \\
\hline & $\begin{array}{l}\text { (3) The building of the museum is designated as an important } \\
\text { cultural property. }\end{array}$ \\
\hline \multirow{3}{*}{$\begin{array}{l}\text { Onomichi } \\
\text { 尾道水道 }\end{array}$} & (1) It is a port town prospered as a key point of shipping in Japan. \\
\hline & (2) You can enjoy night view in the evening. \\
\hline & (3It is also known as the filming location of many movies. \\
\hline \multirow{3}{*}{$\begin{array}{l}\text { Kousanji temple } \\
\text { 耕三寺博物館 }\end{array}$} & (1) It is a museum built by a businessman on his own in 1952 . \\
\hline & (2) Many important cultural property are exhibited. \\
\hline & (3)The building imitates various famous shrines in Japan. \\
\hline \multirow{3}{*}{$\begin{array}{l}\text { Setoda } \\
\text { 瀬戸田 未来心の丘 }\end{array}$} & $\begin{array}{l}\text { (1) It is a garden made as a sculptor's art activity on the island } \\
\text { floating in the Seto Inland Sea. }\end{array}$ \\
\hline & (2) From the top you can see the islands in the Seto Inland Sea. \\
\hline & (3) All of the garden is made up of white marble mined in Italy. \\
\hline
\end{tabular}

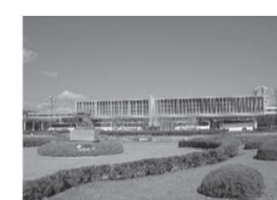

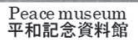

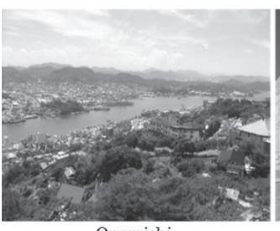

Onomichi

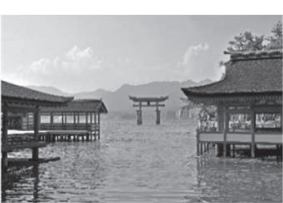
It sukushima Shrine
敬岛神社



Setoda
瀨戸田 末僁の丘

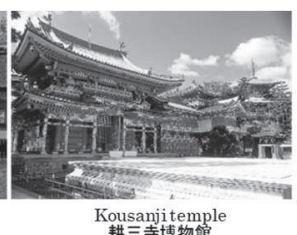

Kousanjitemple
耕三寺楳物館

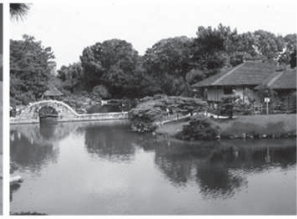

Shukkeien
㛀暴園

Photo1 Landscape photographs

Table2 Experiment days 注 6)

\begin{tabular}{|c|c|c|c|c|}
\hline & \multicolumn{2}{|c|}{ Chinese } & \multicolumn{2}{|c|}{ Japanese } \\
\hline & date & temperature & date & temperature \\
\hline $\begin{array}{l}\text { Onomichi } \\
\text { 尾道水道 }\end{array}$ & $\begin{array}{l}\text { 16/11/2016 } \\
\text { fine }\end{array}$ & $14.4^{\circ} \mathrm{C}$ & $\begin{array}{l}\text { 28/9/2017 } \\
\text { cloudy }\end{array}$ & $23.8^{\circ} \mathrm{C}$ \\
\hline $\begin{array}{l}\text { Kousanji temple } \\
\text { 耕三寺博物館 }\end{array}$ & $\begin{array}{l}\text { 16/11/2016 } \\
\text { fine }\end{array}$ & $15.6^{\circ} \mathrm{C}$ & $\begin{array}{c}\text { 28/9/2017 } \\
\text { cloudy }\end{array}$ & $24.8^{\circ} \mathrm{C}$ \\
\hline $\begin{array}{l}\text { Setoda } \\
\text { 瀬戸田 未来心の丘 }\end{array}$ & $\begin{array}{l}\text { 16/11/2016 } \\
\text { fine }\end{array}$ & $15.5^{\circ} \mathrm{C}$ & $\begin{array}{l}\text { 28/9/2017 } \\
\text { cloudy }\end{array}$ & $25.3^{\circ} \mathrm{C}$ \\
\hline $\begin{array}{l}\text { Shukkeien } \\
\text { 縮景園 }\end{array}$ & $\begin{array}{l}15 / 11 / 2016 \\
\text { fine }\end{array}$ & $21.1^{\circ} \mathrm{C}$ & $\begin{array}{l}29 / 9 / 2017 \\
\text { fine }\end{array}$ & $23.0^{\circ} \mathrm{C}$ \\
\hline $\begin{array}{l}\text { Peace museum } \\
\text { 平和記念資料館 }\end{array}$ & $\begin{array}{l}15 / 11 / 2016 \\
\text { fine }\end{array}$ & $20.0^{\circ} \mathrm{C}$ & $\begin{array}{c}29 / 9 / 2017 \\
\text { fine }\end{array}$ & $24.8^{\circ} \mathrm{C}$ \\
\hline $\begin{array}{l}\text { Itsukushima Shrine } \\
\text { 厳島神社 }\end{array}$ & $\begin{array}{c}14 / 11 / 2016 \\
\text { rain }\end{array}$ & $14.5^{\circ} \mathrm{C}$ & $\begin{array}{l}\text { 29/9/2017 } \\
\text { fine }\end{array}$ & $23.9^{\circ} \mathrm{C}$ \\
\hline
\end{tabular}

対象観光地についての知識や経験を有しており，非居住者よりも親 近感を有していると想定できる者とした。

\section{2. 実験概要}

本研究では, 訪問前の事前情報による印象を求める画像評価実験 と，訪問後の実空間による印象を求める現場実験を実施した。 


\section{1 画像評価実験}

ここでは, 被験者に広島県の観光地 32 ヶ所の景観写真 ${ }^{9)}$ とそれに 関する 3 種類の説明文を事前情報として呈示し, 評価を求めた。呈 示した説明文を表 1 に示す。実験手順としては, まずフェイスシー トへの記入を求め, 次に, 各観光地に対する評価を順次求めた。後 者について, 観光地 1 ヶ所を評価するにあたっては, はじめに観光 地に関する説明文をスクリーン上及び回答票に呈示し, 10 秒間黙読 させた。その後, その観光地の景観写真をスクリーン上に呈示し, 10 秒間眺めさせた後, 1 分 40 秒を目安に回答票の質問項目への記 入を求めた。なお, 中国人被験者に対しては, フェイスシート記入 後, 各観光地に対する評価を求める前に, 広島県に関する簡単な説 明を 5 分程度行った。

被験者は大連理工大学と大連民族大学に在学中の中国人学生 22 名（男女比 $1: 1$ ) と, 広島大学に在学中の日本人学生 21 名（男女 比 $2: 1$ ) で, 両者とも建築系を専門としている。実験日及び実験場 所は, 前者は訪日前である 2016 年 9 月 5 日で大連理工大学講義室, 後者は 2017 年 9 月 27 日で広島大学講義室である。

\section{2 現場実験}

ここでは被験者の興味を惹いた事物を選択させるキャプション評 価実験と, 前節で呈示した観光景観画像と同一の視点場, 視線方向 を眺めさせ, 改めて評価を求める実空間評価実験の 2 種類の実験を 連続して実施した。

対象とした観光地は画像評価実験で対象とした広島県の観光地 32 ケ所の中から 6 ケ所を選定した注 3)。対象地の景観写真を写真 1 に示す。観光地 1 ケ所について，まずキャプション評価実験注 4)を， その後に実空間評価実験を実施した。

被験者は画像評価実験と同一の中国人学生 20 名注 5), 日本人学生 21 名である。実験日を表 2 に示す。なお, 中国人被験者の厳島神社 訪問時は悪天候ではあったものの, 社殿内の見学が主となる観光地 であるため, 大きな問題はないと判断した。

\section{3 回答票の内容}

回答票の内容を表 3 に示す。観光地に対する全体的な評価として, 画像評価実験（以降，[画像]）では既往研究 10) と同様に「訪問希望 の有無」を用いている。実空間評価実験（以降，[実空間]）では， すでに対象地に到着しているため,「訪問希望の有無」は適切ではな いと判断し,「満足度」を用いた。また, 両実験に共通して「訪問希 望の有無 (満足度)」のほか, 「関心の有無」「母国らしさの有無（中 国人のみ)」「日本らしさの有無」，SD 法によるイメージ評価を尋敞 ているが, [実空間]ではさらに, 実際に観光してみた印象として「観 光のしやすさ」や「安全度」, 個々の物理環境の快適さなどを追加で 尋ねた。本論文では, 訪問前後の印象の比較を目的としているため, [画像] [実空間]の双方で尋漦ている総体的評価と SD 法によるイ メージ評価の結果を主として用いることとし，[実空間］のみで尋㸚 ている項目の結果については割愛する。なお, 回答票の内容は日中 両被験者において概衫同一であるが，中国人被験者に対しては中国 語に翻訳して使用している。

以降, 中国人被験者を中国人, 日本人被験者を日本人と表記する。 また, [画像] での中国人被験者数は 22 名だが [実空間]では 20 名 であるため，次章以降の分析では 20 名による結果を示す。
Table3 Contents of the questionnaire

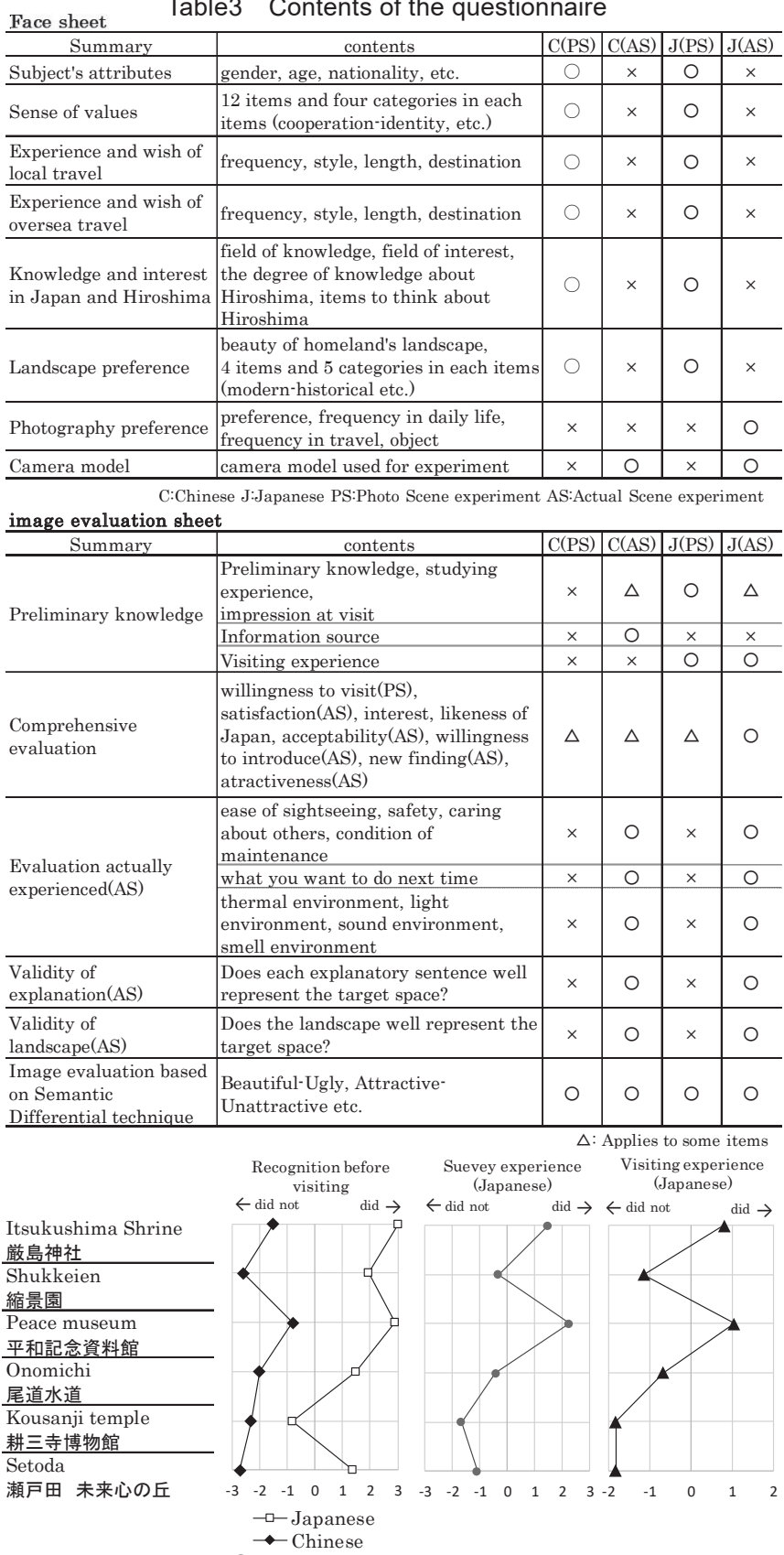

Fig.1 Subject recognition and experience

\section{3. 被験者の認識}

図 1 に観光地に関寸る被験者の認識と経験について, 4 段階尺度 の回答には+3〜-3, 5 段階尺度の回答には+2〜-2 の得点を付与して 求めた平均評価得点プロフィールを示寸注7)。訪問前の認識に関して, 中国人ではその観光地を知っているとの回答がほとんどみられなか ったのに対して，日本人ではいずれの観光地についてもよく知って いる側の回答が多く, 中国人に比べて対象とした観光地をよく認識 していることがわかった。さらに，日本人における，その観光地を 訪問した経験や，どんな場所か調べた経験についてみるなら，被験 者全員にそれら経験が全くない観光地は 1 ケ所もなく，何らかの知 識や経験を有していた。以上から，中国人と日本人では対象とする 観光地の知識や経験に顕著な違いのあることが把握され, 両者を非 居住者と居住者として扱う妥当性が確認された。 


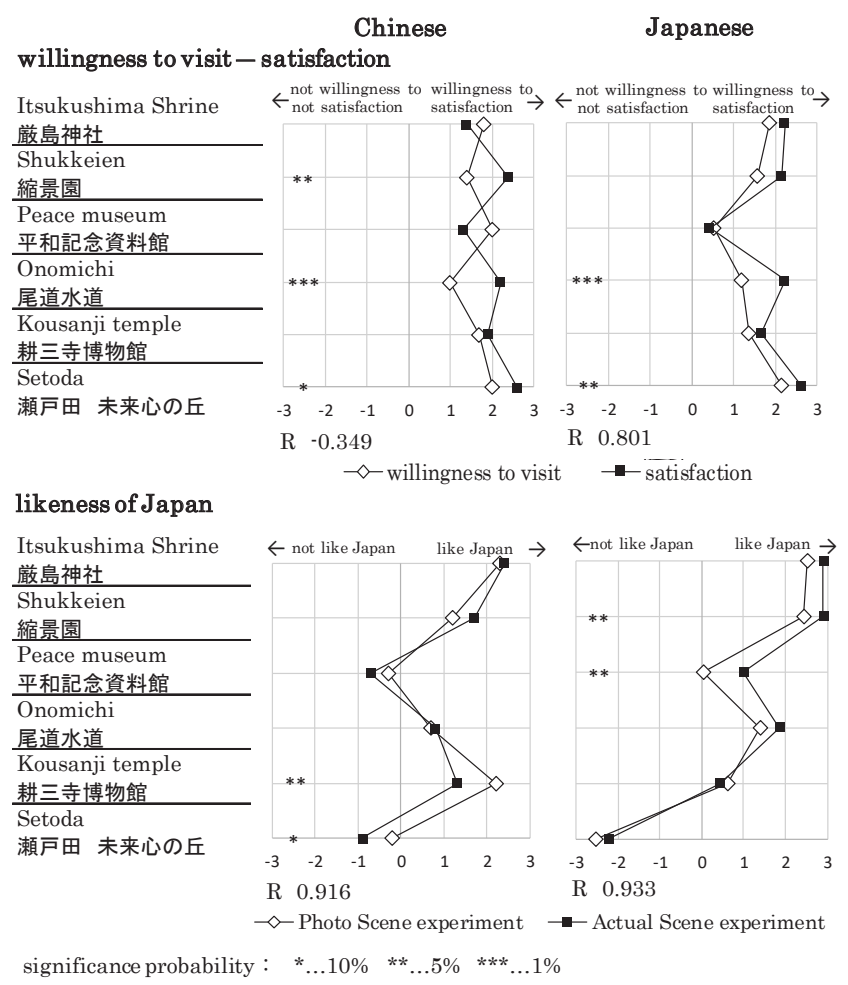

Fig.2 Average evaluation score

\section{4. 心理的評価傾向の比較分析 \\ 4. 1 総体的評価結果}

対象とした 6 ケ所の観光地に対する総体的評価項目「訪問希望の 有無一満足度」注 8)「日本らしさの有無」について, 日中それぞれの [画像］[実空間］それぞれにおける 4 段階尺度の回答に基づいて， 前章と同様に求めた平均評価得点プロフィールを図 2 に示す。さら に［画像］[実空間］間での，対応のある $\mathrm{t}$-検定結果，及び，相関分 析結果も図中に併せて示す。

現地訪問後の「満足度」と訪問前の「訪問希望の有無」の比較で は, 日中共に過半の観光地において前者が後者より高く評価されて いる。これより, 実際に訪問し, 事前情報ではわからない新たな発 見や, 視覚以外の情報, その場でしか味わえない臨場感を得ること で, 評価の高まる傾向が, 居住者, 非居住者という知識の有無を問 わずみられることがわかった。しかしながら, 中国人の場合, 例外 として厳島神社と平和記念資料館において前者が後者を下回ってい る。この 2 地点は有名な観光地であることや, 世界遺産であること， 著名な建築家の作品であることなどの情報を説明文として付与した ために, 事前の期待值が高かったものと予想され, 現地では想像以 上には感じられなかった可能性が示唆される。また, 厳島神社は実 験時に雨が降っていたため, 視界の悪さや温熱環境などの影響も考 えられる。

また，日中共に縮景園，尾道水道，瀬戸田 未来心の丘における ［画像］［実空間］の評価差が他の観光地と比べて大きく，「満足度」 が「訪問希望の有無」より高く評価されている。縮景園は回遊式庭 園であり，実際に歩き回って体験することで，開放感を得ると共に 園内に点在寸る様々な事物を発見し, [画像] では分からなかった日 本の特徴を見出したものと考えられる。尾道水道と瀬戸田未来心 の丘は周辺を見下ろす眺望の得られる観光地であり, そこから開放
感をより強く感じたものと考えられる。また, 後者に関しては大理 石で構成された庭園であることから，各所に置かれた彫刻から，縮 景園と同様にその珍しさを感じた可能性も示唆される。さらに，こ れら観光地では，日本人より中国人の評価の向上が大きいが，既報 11)で示した，中国人の開放性をより重視する傾向が影響を及ぼして いるものと推察される。

「日本らしさの有無」に関して, 縮景園では日中共に［画像］よ り［実空間］が高く評価されている。これは，画像には表れていな い様々な視覚的体験を通して, 日本的特徵をより強く認識したもの と考えられる。厳島神社, 尾道水道と平和記念資料館について, 日 本人では縮景園と同様の傾向がみられたものの，中国人では，前者 2 力所は［画像］と［実空間］が同程度に評価されており，後者は [画像］より [実空間］が低く評価されている。厳島神社ではそこ で行われる儀式等の意味合いや狛犬などの事物，尾道水道では眺望 景に含まれる遠方のしまなみ海道の橋梁群や向島ドックなど様々な 事物が有する意味合い，そして平和記念資料館では景観写真には含 まれない軸線上に遠望可能な原爆ドームや散在する慰霊碑など, 日 本や広島の歴史や文化背景を感じさせる体験を通して，日本人はい ずれの観光地にも日本的特徴を現地でより感じたのに対して, 現地 に臨んでも中国人にはその意味が十分に理解されなかったものと推 察される。

一方で，耕三寺博物館と瀬戸田 未来心の丘では中国人では［実 空間］が［画像］より低く評価されている。中国風の伝統的な建築 物が主な視対象である前者に関しては，中国人は［画像］の段階で はその伝統性を感じ取り，高い日本らしさを感じていたものの，現 地の観察で母国との共通点を見出すことにより，全体的な印象とし て感じ取る日本特有の雰囲気が弱まったものと考えられる。日本人 でも若干同様の傾向がみられるものの, 以前より日本や耕三寺博物 館に対する知識や経験を有しており, 訪問前から正確なイメージが できたため，中国人ほど [実空間］の評価が低下しなかったと考え られる。

後者では, 中国人は［画像］の段階では，母国にない珍しい景観 ではあるものの，それが日本的なのかどうか判然としなかったとこ ろが，各観光地一の訪問を重补，日本についての知識が増え，日本 らしさをより明確にイメージ可能になったため，日本らしくはない とする判断がより強まったものと考えられる。一方日本人は, 周辺 の景色から見られる街並みから[画像］よりも若干強く日本らしさ を感じとったものと考えられる。

以上より，日本に対する知識を有していない中国人は，実際に観 光地を訪問し，日本の文化や風物を経験，学習することで，その観 光地が日本的かどうかのより明確な判断が可能になったものと予想 される。一方, 日本の歴史, 伝統や文化, またその観光地に対して 中国人よりも多くの知識を有している日本人は，現地での様々な情 報の有する意味を認識することによって，耕三寺博物館を除くす心゙ ての観光地で訪問後に評価が向上寸る傾向が認められた。

\section{2 SD 法によるイメージ評価結果}

日中両被験者の SD 法によるイメージ評価 13 形容詞対について 共通する因子を抽出するため, 中国人，日本人それぞれに対して［画 像］［実空間］の統合データに主因子法，バリマックス回転による因 子分析を適用した。また，日中全被験者全 4 種類の統合データにつ 
Table4 Results of factor analysis

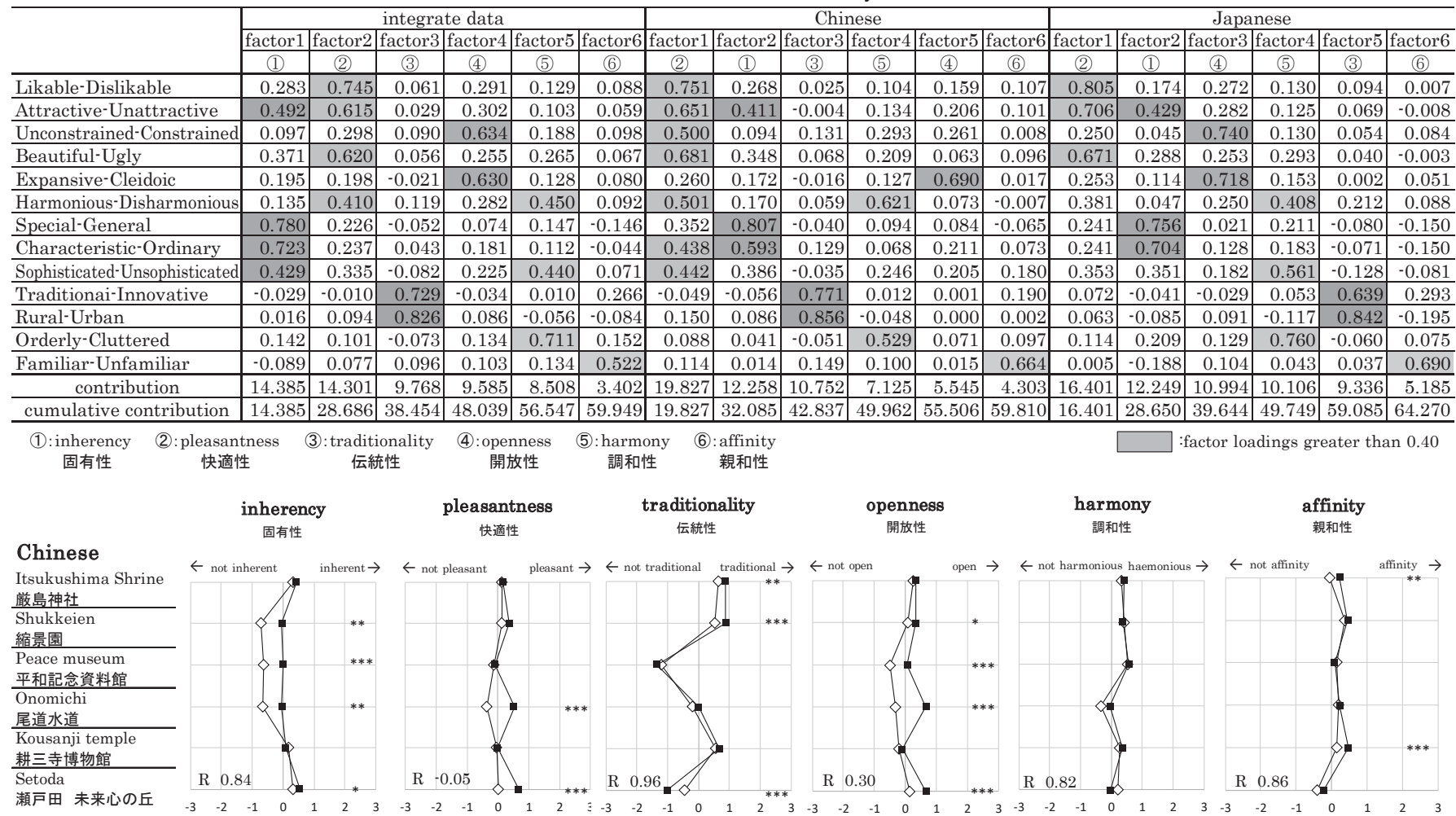

\section{Japanese}
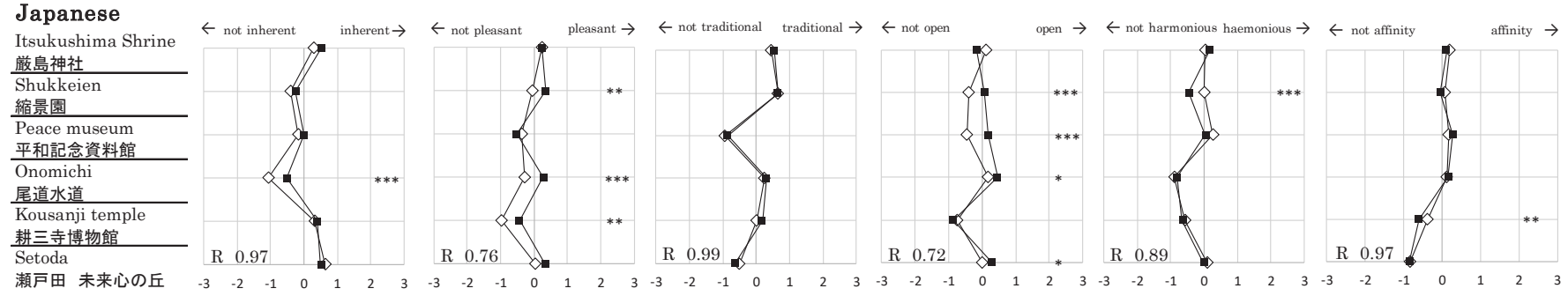

significance probability : $* \ldots 10 \%{ }^{* *} \ldots .5 \%{ }^{* * *} \ldots 1 \%$

Fig.3 Average factor profile

いても同様に適用した注9)。結果を表 4 に示す。抽出順に若干の違い はみられるものの, 3 者共にほぼ共通の 6 因子が抽出されている。 各因子はそれぞれ, 特別感や特徴を表す『固有性』, 総合的な好みや 魅力を表す『快適性』, 伝統や都会的な印象を表す『伝統性』, 開放 感を表す『開放性』, 秩序や調和を表す『調和性』, 馴染夕深さを表 す『親和性』と解釈でき, 日中の共通性がうかがえる。ただし, 中 国人では『固有性』を特徴づける形容詞対の因子負荷量が,『快適性』 でも比較的高い值を示すことから, 日本の特徽的な事物に対して総 体として好ましく感じている可能性が推察される。

次に, 全被験者の結果に基づき, 日本人と中国人それぞれについ て, [画像］[実空間］ごとに各観光地の平均因子得点を求めた。結 果をプロフィールとして図 3 に示す。なお, 図 2 と同様に $\mathrm{t}$-検定結 果，相関分析結果を併せて示す。

これより, 日中共に多くの因子において, [実空間］が［画像］よ り高く評価される傾向がみられる。臨場感が得られ, より多くの詳 細な情報を取得可能な現地での観察によって, 各因子の示寸特性が より強く感じられたのではないかと予想される。中でも, 『固有性』 『快適性』『開放性』では有意差のある観光地が多く, 顕著な傾向が
認められることから, 観光地による違いはあるものの, 現地での経 験は特別感や好ましさ，開放感などに特に大きな影響を及ぼすこと が予想される。一方, 『調和性』や『親和性』は［画像］と［実空間］ で大きな評価差がみられないことから, 整然さや調和感, 馴染み深 さなどは［画像］の段階でほぼ［実空間］と同様の評価が可能であ り，むしろ個人差が大きい可能性が示唆される。

日中で特徴的な傾向を比較するなら, 前述した 3 因子について中 国人は，日本人より全体的に［画像］に対する [実空間］の評価の 向上が大きいことがわかる。中国人は日本やその観光地に対する知 識が豊富ではなく, [画像]の段階ではその観光地の実際の状況を正 確に想像できなかった可能性があることから, 現地での臨場感や多 様な情報の影響をより強く受け, 認識に変化が生じたと予想される。 特に, 尾道水道と瀬戸田未来心の丘で『快適性』『開放性』の向 上が他の観光地と比べ顕著である。これらは高所より俯瞰的に景色 を見下ろす観光地であるため, 前述した日本人より開放感をより重 視する中国人の特性が影響し, 総合的な好ましさをより強く感じた ものと推察される。

一方, 日本人では, [画像] と［実空間］の相関係数を比較するな 
Table5 Correlation coefficients

\begin{tabular}{|c|c|c|c|c|c|c|c|}
\hline & & (1) & (2) & (3) & (4) & (5) & (6) \\
\hline \multirow{4}{*}{$\begin{array}{l}\text { willingness to } \\
\text { visit- } \\
\text { satisfaction }\end{array}$} & $\mathrm{C}(\mathrm{PS})$ & 0.547 & 0.499 & -0.319 & 0.180 & 0.758 & -0.598 \\
\hline & C(AS) & 0.105 & 0.844 & 0.040 & 0.609 & -0.749 & -0.159 \\
\hline & $J(\mathrm{PS})$ & 0.517 & 0.496 & 0.420 & 0.407 & 0.090 & -0.564 \\
\hline & $\mathrm{J}(\mathrm{AS})$ & 0.136 & 0.870 & 0.488 & 0.133 & -0.175 & -0.457 \\
\hline \multirow{4}{*}{$\begin{array}{c}\text { likeness of } \\
\text { Japan }\end{array}$} & $\mathrm{C}(\mathrm{PS})$ & 0.386 & 0.390 & 0.912 & 0.394 & -0.004 & 0.291 \\
\hline & C(AS) & -0.121 & -0.174 & 0.963 & -0.189 & 0.275 & 0.761 \\
\hline & $J(\mathrm{PS})$ & -0.486 & 0.125 & 0.772 & 0.026 & -0.214 & 0.827 \\
\hline & $\mathrm{J}(\mathrm{AS})$ & -0.453 & 0.125 & 0.738 & -0.041 & -0.136 & 0.785 \\
\hline \multicolumn{4}{|c|}{ anes } & \multicolumn{4}{|c|}{ 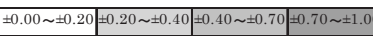 } \\
\hline
\end{tabular}

PS:Photo Scene experiment AS:Actual Scene experiment

Table6 Results of multiple regression

C(Photo Scene experiment)

\begin{tabular}{|c|c|c|c|c|c|c|c|}
\hline \multirow{2}{*}{$\mathrm{R}^{\wedge}$} & \multicolumn{6}{|c|}{ standardised partial regression coefficient } & \multirow{2}{*}{$\begin{array}{l}\text { significance } \\
\text { probability }\end{array}$} \\
\hline & (1) & (2) & (3) & (4) & (5) & (6) & \\
\hline 0.377 & 0.430 & 0.237 & -0.176 & 0.066 & 0.121 & 0.052 & .000 \\
\hline \multicolumn{8}{|c|}{ C(Actual Scene experiment) } \\
\hline \multirow{2}{*}{$\mathrm{R}^{\wedge}$} & \multicolumn{6}{|c|}{ standardised partial regression coefficient } & \multirow{2}{*}{$\begin{array}{l}\text { significance } \\
\text { probability }\end{array}$} \\
\hline & (1) & (2) & (3) & (4) & (5) & (6) & \\
\hline 0.280 & 0.285 & 0.383 & 0.109 & 0.134 & 0.054 & 0.028 & .000 \\
\hline \multicolumn{8}{|c|}{ J(Photo Scene experiment) } \\
\hline \multirow{2}{*}{$\mathrm{R}^{\wedge}$} & \multicolumn{6}{|c|}{ standardised } & \multirow{2}{*}{$\begin{array}{l}\text { significance } \\
\text { probability }\end{array}$} \\
\hline & (1) & (2) & (3) & (4) & (5) & (6) & \\
\hline 0.295 & 0.204 & 0.401 & -0.217 & 0.122 & -0.018 & -0.094 & .000 \\
\hline
\end{tabular}

J(Actual Scene experiment)

\begin{tabular}{c|c|c|c|c|c|c|c}
\hline \multirow{2}{*}{$\mathrm{R}^{\wedge}$} & \multicolumn{3}{|c|}{ standardised partial regression coefficient } & significance \\
\cline { 2 - 7 } & $(1)$ & $(2)$ & $(3$ & 4 & $(5)$ & $(6$ & probability \\
\hline 0.165 & 0.209 & 0.233 & -0.217 & -0.008 & 0.046 & -0.016 & .001 \\
\hline
\end{tabular}
$\mathrm{C}$ :Chinese J:Japanese

$\begin{array}{cccc}\text { (1): inherency } & \text { (2): pleasantness } & \text { (3): traditionality } & \text { (4): openness } \\ \text { 固有性 } & \text { 快適性 } & \text { 伝統性 } & \text { 開放性 } \\ \begin{array}{cc}\text { (5): harmony } \\ \text { 調和性 }\end{array} & \begin{array}{c}\text { (6): affinity } \\ \text { 親和性 }\end{array} & & \end{array}$

ら，いずれの因子においても中国人を上回っていることがわかる。 これは, 自らの知識や経験から, 対象とする観光地の見所や特徵な どが既知であったことにより, [画像]の段階でかなりの程度, 実際 の状況の予想が可能であり, [実空間]でも大きな差が生じなかった ことによると考えられる。ただし, 他の因子に比較して『快適性』 や『開放性』では相関が劣ることから，日本人の場合もこれら因子 では現地の状況が評価に及ぼす影響がより大きいものと予想される。

\section{5. 心理的評価構造の比較分析}

\section{1 総体的評価項目と各因子との関連}

これまで，総体的評価と各因子の評価傾向の特徵について，各観 光地に着目して検討してきたが，本節では両者の関連について，よ $り$ 全体的な観点から検討する。総体的評価 2 項目の平均評価得点と 6 因子の平均因子得点から求めた相関係数行列を表 5 に示す。

これより,「訪問希望の有無一満足度」については, 『固有性』『快 適性』では日中共に [画像]ではある程度の関連がみられるものの, [実空間］では前者はほとんど関連がみられず，後者では 0.8 以上 の強い関連が認められ, 影響が大きく異なる。評価項目の意味内容 の違いによる可能性も考えられるが, [画像] の段階では特徴的な観 光地にある程度訪問意欲を喚起されるものの, 実際に訪問すると特
別なものより好ましい観光地により満足する傾向があると言える。 一方，『開放性』に関しては，中国人では [実空間］で相関係数が高 いのに対して日本人では逆の傾向がみられる。これより，日本人と 比べて中国人は [実空間］においてより開放的な観光地に対して満 足感を覚える傾向が強いものと考えられる。なお, 中国人の場合,

『調和性』について [画像]では正の，[実空間］では負の相関がみ られるが，前述した縮景園や尾道水道，瀬戸田未来心の丘の評価 の変化によるものと予想される。

「日本らしさの有無」との関連では, 中国人は『伝統性』との相 関が [画像，［実空間］いずれも高く，基本的に伝統的であれば日 本的であると評価する傾向が強いと言える。一方，『伝統性』以外の 因子では，［画像］と［実空間］との間で関連の強さに変化が認めら れ，『固有性』『快適性』『開放性』などの関連がいずれも低下寸るの に対し，『調和性』や『親和性』では増加しており，特に『親和性』 で著しい。これに対して日本人では，いずれの因子も［画像］と［実 空間］で相関係数の值に変化がみられず，評価傾向に大きな差がな いことから,「日本らしさの有無」との関連についても [画像]と [実 空間】でほとんど差がなく,『伝統性』と『親和性』で相関が高い傾 向を示す。これらの結果より, 日本人では『伝統性』のほかに馴染 みがあるかどうかが「日本らしさの有無」に大きく影響しており， 中国人も日本での経験や様々な観光地の訪問を通して, 日本に対す る理解が深まり，日本人と同様に『親和性』の影響が高まったので はないかと考えられる。

\section{2 重回帰分析による評価構造の比較}

前節では， 6 観光地に対する平均的な評価結果に基づき, 総体的 評価と各因子との単純な関係について検討したが，本節では，「訪問 希望の有無一満足度」がそれら因子によってどの程度説明されるか を，因子間の相互影響を考慮し，素データに基づいて検討する。[画 像では「訪問希望の有無」，[実空間］では「満足度」を目的変数 とし，6 因子を説明変数として，日本人，中国人それぞれに対して 重回帰分析を適用した。結果を表 6 に示寸注10)。

これよりまず，中国人，日本人ともに［画像］に比べ［実空間］ では決定係数の值が低下寸ることがわかる。すなわち，[画像］では 統一的かつ制限された情報が与えられたことにより，異なる観点か らの評価であるにもかかわらず十分に違いが現れず，イメージ評価 によって説明できる部分が大となり，個人の搘好が大きく反映され ないのに対して, [実空間] では物理環境要素を含む多様な情報が呈 示され，それぞれに対する個人ごとの重視の仕方も異なるため，イ メージ評価によって説明できる部分が低下したものと考えられる。 次に, 標準偏回帰係数の值から, 日中, 並びに, [画像］と［実空間］ の違いについて考察する。中国人については, [画像]では『固有性』 の説明力が最も高く, 次いで『快適性』となるのに対して, [実空間] では『固有性』の説明力が低下寸る傾向が認められ，おおよそ前節 と同等の傾向が得られている。また,『伝統性』に関しては, 説明力 の大きさにはあまり変化がみられないものの，[画像］と［実空間］ で正負の值が逆転していることがわかる。『固有性』の変化と併せて 考察するなら, [画像] の段階では, 何か特別なものや珍しいもの, 都会的な事物への期待が強い傾向がみられるのに対して， [実空間] の段階ではそれらの事物が評価に与える影響が弱まり，伝統的な事 物の価值を認める傾向に転じた可能性が示唆されたと解釈できる。 
これより中国人は日本での経験, 各観光地一の訪問を通して歴史や 文化を理解し, 馴染んだ結果, 単なるもの珍しさではなく, 日本本 来の特徵を尊重し, 評価する立場に変化したものと考えられる。

日本人に関しては，[画像］では『快適性』の説明力が最も高く, 次いで『固有性』『伝統性』が高いのに対して，[実空間］では『快 適性』が大きく低下し, 『固有性』『伝統性』の比重が相対的に増し ている。[画像］と［実空間］での各因子の影響の変化を, 前節の相 関分析の結果と比較寸るなら, 『固有性』や『快適性』で傾向が異な り, それら因子で傾向が共通する中国人と異なっている。これは, 各観光地に対する平均的な評価結果に基づく評価構造と, 個人によ る違いをふまえた評価構造との違いを示寸ものと思われる。[画像］, [実空間] 共に中国人より決定係数が低いことも考慮するなら, 日本 人の場合, 豊富な知識や経験などに基づいた, 個人によっても異な る価值判断基準を有している可能性が示唆される。

\section{6. おわりに}

本研究では非居住者である中国人による広島県の観光地に対する, 訪問前の印象と訪問後の印象との差を, 居住者である日本人の結果 と比較検討し評価傾向を明らかにした。その結果以下の知見を得た。

「訪問希望の有無一満足度」について, 非居住者の中国人, 居住者の日本人にかかわらず，実際に現地を訪問し，新たな発 見や情報の取得, 臨場感を得ることで満足感が高まる傾向が認 められた。また, 非居住者である中国人は, 事前の期待值が高 い観光地では, 実際に訪問した際に想像していた以上に感じら れず，「満足度」が低下する可能性が示唆された。

(2)「日本らしさの有無」については, 非居住者の中国人では, 日本での経験によって判断基準がより明確になる傾向がみら れた。一方, 居住者の日本人では, 現地での様々な情報の有す る意味を認識することによって，ほぼいずれの観光地でも訪問 後に評価の向上寸る傾向が認められた。

(3) SD 法によるイメージ評価では, 『固有性』『快適性』『伝統性』 『開放性』『調和性』『親和性』の 6 因子が共通して抽出され， このうち, 『固有性』『快適性』『開放性』の 3 因子について, 現地訪問によって評価が向上する傾向がみられ，その傾向は非 居住者である中国人でより大きく, 中国人の開放感を重視する 傾向が確認された。一方, 居住者である日本人では訪問前の事 前情報による評価と訪問後の評価とで, 非居住者である中国人 と比べ評価傾向の共通性が高いことを示した。

(4) 総体的評価項目と各因子との関連について, 日中共に訪問前 は特徵的な観光地に訪問意欲を喚起されるものの, 訪問後は特 別なものより好ましい観光地により満足する傾向がみられた。 また，非居住者の中国人は，訪問前は知識が乏しく「日本らし さ」を『伝統性』で判断する傾向がみられたが, 訪問後は体験 を通して日本に対する理解が深まり，居住者の日本人と同様に， 『親和性』による影響が認められた。

(5) 居住者である日本人と, 非居住者である中国人の心理的評価 構造の比較のため重回帰分析を適用した結果，日中共に，訪問 前に比べ訪問後は, 得られる情報量が増加することで, それぞ れに対する個人ごとの感じ方の多様性が反映され, イメージ評 価各因子によって説明できる部分が低下したものと推察され
た。また，非居住者である中国人では，訪問前は特別で珍しい 要素や都会的な事物による影響がみられたが，日本の歴史文化 への理解が深まることで, 訪問後は日本の固有性を尊重し, 評 価するようになったことを把握した。

最後に, 本研究の成果を踏まえた上で, 今後の展開について述心 る。本報では非居住者である中国人の訪問前後の評価構造の差異を 概括するに留まっているが，訪問後に日本的な特徵に関心を示し， 満足感を得るようになった可能性が示唆されたことから，各観光地 のいかなる箇所に日本的特徴を感じ取ったのか，その要因を把握す ることで, より具体的な評価構造を明らかにすることが可能である と考えられる。このため, 本報では割愛したが, キャプション評価 実験の結果を分析することで非居住者である中国人の観光地におけ る着目点を整理し，観光地の総体的な評価構造との関連を分析する 必要がある。さらにその結果を居住者である日本人の評価構造と比 較することで, 中国人の特徴的な評価傾向の明確化が可能となり, 非居住者としての中国人観光客が魅力的と感じる具体的な観光資源 獲得のための資料となり得ると推察される。また，本研究では非居 住者として中国人観光客を対象としたが，訪日客数が相対的に少な く, 日本とは文化背景が大きく異なる欧米諸国など他の国籍の観光 客の評価傾向を解明することで，より多面的な観光資源獲得が期待 できる。

\section{謝辞}

本研究は，JSPS 科研費 18K11869 の助成を受けたものです。ま た，本研究の心理的評価実験を実施するにあたり，協力してくださ った被験者の皆様，大連理工大学並びに大連民族大学の諸先生方に 感謝の意を表します。

\section{注}

注 1)事前情報として呈示したのは観光景観画像 1 枚と説明文 3 種類である。 これは一般的なガイドブックなどで，ある名所を紹介するための最低限の 情報としては写真 1 枚と簡単な紹介文であると考えたことによる。説明文 の選定理由としては, 実際の当該観光地の最低限の内容を示していること, 相互に独立した内容であると考えられることを考慮し，ガイドブックや書 籍などを参照して設定した。また，一般的な情報取得量は観光地によって 異なるが，本研究では観光地間の比較は行わず，日本人学生と中国人学生 の訪問前後での印象の差異を総合的に検討するため, 観光地によってサン プルの質に偏りが生じることのないよう，呈示した情報量は全ての観光地 で統一した。

注 2)中国人被験者は，広島大学と大連理工大学，大連民族大学合同のワーク ショップに参加した学生である。いずれの観光地を訪問するかは予め知ら せていないが，ワークショップに参加するため広島を訪問することは事前 に了解しており，画像評価実験の冒頭で広島県に関する簡単な紹介を受け ている。また，訪問後はキャプション評価実験として，各観光地に設定さ れた範囲内を自由に見学し，興味を惹く対象を写真に撮影させた。これら の行為は一般的な観光客がとる観光行動と比較的共通性が高いと考えられ るため，実際の観光と全く同一とは言えないものの，本研究ではほぼ同等 の経験であるとみなしている。

注 3)既報 5)等の先行研究で特徵的な結果がみられた地点から, 実際に実空間 を体験して周遊することが可能な距離や時間を考慮し選定した。

注 4)実空間における観光体験を模擬する実験である。対象範囲は, 対象とす る観光地を見学するのに概衩妥当な見学範囲と重なるように設定し, その 中で自由行動をさせた。また，実験時間は，予備実験の結果や対象範囲の 広さなどから適切な時間を設定したため, 各観光地で異なる。

注 5)当初訪日予定であった学生 22 名について [画像] 評価実験を実施した が，諸般の事情で訪日できなかった学生が 2 名いたため, 20 名となった。 注 6) 実験時間は厳島神社が 65 分, 縮景園が 80 分, 平和記念資料館が 35 分, 
尾道水道が 25 分, 耕三寺博物館が 55 分, 瀬戸田 未来心の丘が 30 分で ある。各観光地間の移動はバスを用いており, 移動中に被験者間で感想を 言い合うことのないよう教示をした。移動時間は平均で 45 分である。ま た, 一日に 3 地点で実施するよう計画したが, 中国人被験者では宮島 不 消火堂, 弥山山頂, 中工場の 3 ヶ所でも実施したものの, 天候に恵まれな かったため, 晴天日の結果との比較が難しいことや，スケジュールの関係 から，日本人被験者の実験では割愛した。

注 7)被験者の認識に関しては「1. 知っていた，2．やや知っていた， 3 . あまり知らなかった，4 知らなかった」，観光地を調べた経験については 「1.ある，2．少しある，3．あまりない，4.ない」という4 段階の 回答にそれぞれ「3」「1」「-1」「-3」の得点を, 観光地に対寸る訪問経験に ついては「1. 来たことはない, 2 . 1 回, 3. $2 \sim 3$ 回, 4. $4 \sim 5$ 回, 5. 6 回以上」という 5 段階の回答に「-2」「-1」「0」「1」「2」の得点を等 間隔に付与した。

注 8）「満足度」と「訪問希望の有無」は質問項目の意味内容が異なるので, 直接的な比較は難しい側面があるが, ここでは評価傾向など, ある程度の 比較が可能と想定し, $\mathrm{t}$-検定も便宜上適用した。また, 「満足度」の考察に あたっては, その環境に対する満足感であるため, その時点の物理的環境 条件も大きく影響することを考慮した。ただし，環境要素の影響が比較的 少ないと考えられる「友人・知人への推薦度」も併せて尋ねているが，「満 足度」とほぼ同様の評価傾向が得られている。

注 9)ここでの 3 種類の統合データは全て被験者平均值ではなく個人データを 統合したものである。

注 10)ここでの重回帰分析では, 目的変数に個人ごとの対象とする観光地に 対する 4 段階尺度の回答を用いている。離散変数を回帰しているため, ま た，サンプル数が多いため決定係数は低い值をとるが，観光地毎の 6 サン プルでの分析が困難であること, また, 前節までと異なり個人ごとの違い もモデルに反映されることを意図してここでは適用した。

\section{参考文献}

1) Japan National Tourism Organization(cited 2018-6-20) 日本政府観光局 (JINTO) HP(参照 2018-6-20) http://www.jnto.go.jp/jpn/reference/tourism_data/visitor_trends/

2) Naoi, T. Soshiroda, A. and Iijima, S.: The aspects of local lives in a historical district as a tourism destination-Objects of visitors' gaze and their evaluation by residents-, Journal of the City Planning Institute of Japan, Vol.48 No.1, pp.82-87, 2013.4 (in Japanese)

直井岳人, 十代田朗, 飯島祥二 : 観光地としての歴史的町並みにおける地 元の生活の様相-訪問客のまなざしの対象と, それに対する住民の評価-, 日本都市計画学会都市計画論文集 Vol.48, No.1, pp.82-87, 2013.4

3) Baek, L. Soshiroda, A. and Tsutsumi, T.: Study on Advantages and Problems of Tourism-based Community Design with Residents Participation through Perception of Residents and Tourists-In case of Dongpirang of South Korea-, Journal of the City Planning Institute of Japan, Vol.51 No.1, pp.13-22, 2016.4 (in Japanese)

白りな, 十代田朗, 津々見崇: 住民と観光客の意識からみる住民参加による 観光まちづくりの利点と課題, 日本都市計画学会都市計画論文集 Vol.51, No.1, pp.13-22, 2016.4

4) Yamaguchi, Y.: Satisfaction of Foreign Tourists in Shonai Region: A Case of Tour Visitors of Chartered Flights to Shonai Airport, Quarterly Journal of Geography, Vo1.60, pp. 109-113, 2008.6 (in Japanese) 山口泰史 : 庄内地域における外国人旅行者の満足度について一庄内空港于 ヤーター便ツアー客を対象に-, 季刊地理学 Vol.60, No2, pp.109-113, 2008.6

5) Takagishi, H. Nishina, D. Yoshihara, T. Kawase, K. Lu, W. Jin, H. and Tanaka, T.: A Study on the Psychological Evaluation of Tourism Landscape Images in Hiroshima -Psychological evaluation by potential Chinese visitors to Japan-, Journal of Environmental Engineering (Transactions of AIJ), Vol.81, No.726, pp.651-660, 2016.8 (in Japanese) 高岸英子, 西名大作, 吉原俊朗, 川瀬功太, 陸偉, 金華 : 広島県の観光景観画 像に対する心理的評価に関する研究一中国人訪日旅行潜在層を被験者と して一, 日本建築学会環境系論文集, 第 81 巻, 第 726 号, pp.651-660, 2016.8

6) Nose, M. and Furuya, H.: Analysis of Evaluation Characteristics of International and Japanese Tourists in Nikko and Hakone, Journal of the City Planning Institute of Japan, No.43-3, pp.595-600, 2008.10 (in
Japanese)

野瀬元子, 古屋秀樹：日光, 箱根における外国人観光者と日本人観光者の 評価特性分析, 日本都市計画学会都市計画論文集 No.43-3, pp.595-600, 2008. 10

7) Ohkubo, R. and Muromachi, Y: A Study of Destination Images of Foreign Tourists to Japan by Analyzing Travel Guidebook and Review Site Journal of the City Planning Institute of Japan, Vol.49 No.3, pp.573-578, 2014.10 (in Japanese)

大久保立樹, 室町泰徳 : 旅行ガイドブックとロコミの言語解析による訪日 外国人の観光地イメージに関する研究, 日本都市計画学会都市計画論文 集 Vol.49, No.3, pp.573-578, 2014.10

8) Japan Tourism Statistics (Japan National Tourism Organization) (cited 2018-11-19)

日本の観光統計データ (日本政府観光局) HP(参照 2018-11-19)

https://statistics.jnto.go.jp/

9) VISIT HIROSHIMA(cited 2016-8-10) 広島県観光ホームページ (参照 2016-8-10)

http://www.kankou.pref.hiroshima.jp

10) Takagishi, H. Nishina, D. Lu, W. Jin, H. Tanaka, T. Yoshihara, T. and Kawase, K.: A Study on the Psychological Evaluation of Tourism landscape Images in Hiroshima. Part9 -Effects due to add the text information-, Proceedings of annual research meeting Chugoku Chapter, Architectural Institute of Japan, No.38, pp.449-452, 2015.3 (in Japanese)

高岸英子, 西名大作, 陸偉, 金華, 田中貴宏, 吉原俊朗, 川瀬功太 : 広島県の 観光景観画像に対する心理的評価に関する研究 その 9-文字情報付与に よる影響-, 日本建築学会中国支部研究報告集 第 38 巻, pp.449-452, 2015. 3

11) Kawase, K. Nishina, D. Lu, W. Jin, H. Tanaka, T. and Yoshihara, T. A Study on the Psychological Evaluation of Tourism Landscape Images in Hiroshima -Psychological Evaluation by Chinese students, Chinese foreign students and Japanese students-, Journal of Environmental Engineering (Transactions of AIJ), Vol.80, No.708, pp.99-108, 2015.2 (in Japanese)

川瀬功太, 西名大作, 陸偉, 金華, 田中貴宏, 吉原俊朗 : 広島県の観光景観画 像に対する心理的評価に関する研究一中国人学生・中国人留学生・日本人 学生を被験者として一, 日本建築学会環境系論文集, 第 80 巻, 第 708 号, pp.99-108, 2015. 2

12) Takagishi, H. Nishina, D. Lu, W. Jin, H. Tanaka, T. and Yoshihara, T.: A Study on the Psychological Evaluation of Tourism landscape Images in Hiroshima. Part11. -Effect factor of "Hopes to visit" evaluationProceedings of annual research meeting Chugoku Chapter, Architectural Institute of Japan, No.39, pp.517-520, 2016.3 (in Japanese)

高岸英子, 西名大作, 陸偉, 金華, 田中貴宏, 吉原俊朗一広島県の観光景観 画像に対する心理的評価に関寸る研究 その 11-訪問希望の評価への影 響要因-, 日本建築学会中国支部研究報告集 第 39 巻, pp.517-520, 2016. 3

13) Takagishi, H. Nishina, D. Lu, W. Jin, H. Tanaka, T. Yoshihara, T. and Ishikawa, M.: A Study on the Psychological Evaluation of Tourism landscape Images in Hiroshima. Part12 -A comparative analysis on psychological evaluation of text information between Japanese and Chinese-, Proceedings of annual research meeting Chugoku Chapter, Architectural Institute of Japan, No.40, pp.351-354, 2017.3 (in Japanese)

高岸英子，西名大作，陸偉，金華，田中貴宏，吉原俊朗，石川瑞穂：広島 県の観光景観画像に対する心理的評価に関する研究 その 12-文字情報 付与時の日中比較-, 日本建築学会中国支部研究報告集 第 40 巻, pp.351$354,2017.3$

14) Ishikawa, M. Nishina, D. Lu, W. Jin, H. Tanaka, T. Yoshihara, T. and Takagishi, H.: A Study on the Psychological Evaluation of Tourism landscape Images in Hiroshima. Part13. -The evaluation results in the onsite experiment- Proceedings of annual research meeting Chugoku Chapter, Architectural Institute of Japan, No.40, pp.355-358, 2017.3 (in Japanese) 石川瑞穂, 西名大作, 陸偉, 金華, 田中貴宏, 吉原俊朗, 高岸英子: 広島 
県の観光景観画像に対する心理的評価に関する研究 その 13-現場実験 における評価結果-, 日本建築学会中国支部研究報告集 第 40 巻, pp.355-358, 2017. 3

15) Ishikawa, M. Nishina, D. Lu, W. Jin, H. Tanaka, T. and Teraoka, T.: A Study on the Psychological Evaluation of Tourism landscape Images in Hiroshima. Part14 -Comparison of the evaluation results in the onsite experiment between Japanese and Chinese students-, Proceedings of annual research meeting Chugoku Chapter, Architectural Institute of Japan, No.41, pp.477-480, 2018.3 (in Japanese)

石川瑞穂, 西名大作, 陸偉, 金華, 田中貴宏, 寺岡透布子: 広島県の観光 景観画像に対する心理的評価に関寸る研究 その 14-現場実験における 評価結果の日中差異-, 日本建築学会中国支部研究報告集 第 41 巻, pp.477-480, 2018. 3 


\section{A STUDY ON THE PSYCHOLOGICAL EVALUATION OF TOURIST SPOTS IN HIROSHIMA}

Comparison of the results of image-based evaluation and onsite evaluation between Japanese and Chinese students

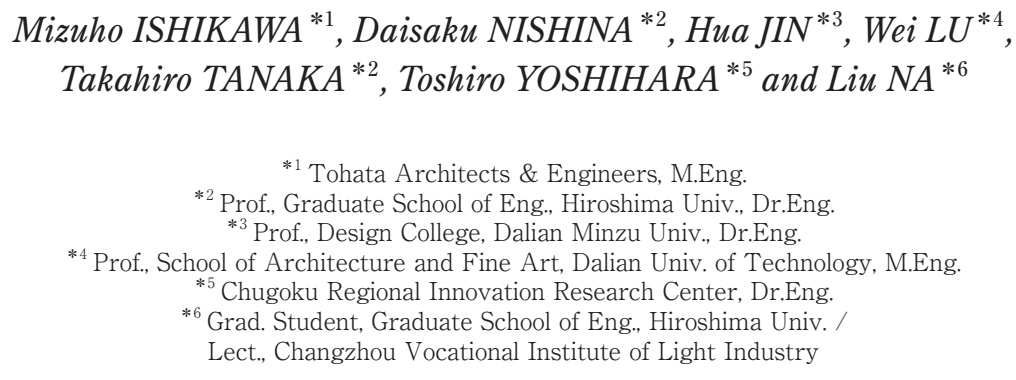

1. Introduction In recent years, the tourism industry is important for revitalizing local cities and improving the quality of life. In Tourism-Based Community, it is required to investigate tourism resources that will be attractive for nonresidents. Meanwhile, globalization is progressing now, and foreign tourists visiting Japan are also increasing. Therefore, in order to discover attractive tourism resources for nonresidents, it is necessary to investigate the needs of foreign tourists as nonresidents for Japanese tourist spots. In addition, tourism behavior is generally carried out in the process of actually visiting after obtaining prior information to determine the destination. Therefore, it's necessary to investigate changes in the impression of tourists to tourist spots before and after visiting. In this study, to get a thorough understanding of attractive tourism resources for foreign tourists as nonresidents, we compared the results of psychological evaluation of tourist spots in Hiroshima obtained by the image-based and onsite experiments using Chinese and Japanese students as nonresidents and residents.

2. Outline of the experiment In this study, image-based evaluation experiment by Photo Scenes (PS) and onsite evaluation experiment were conducted. In the former experiment, we presented landscape photos of 32 tourist spots in Hiroshima and the explanatory texts about them, and then asked subjects to evaluate each tourist spots. The latter experiment contained two parts: the caption evaluation experiment and the Actual Scene evaluation experiment (AS), which asked subjects to view the same scene as the photo of each tourist spot, and to evaluate in the same way as PS. To figure out the difference between the impression from the photo and the explanatory texts and that from the actual space, we discussed the results of PS and AS out of the three experiments.

3. Subject recognition As a result of the recognition and experience of the tourist spot, it turned out that there is a big difference in knowledge and experience to the target tourist spot between the Japanese and Chinese subjects. Therefore, the validity of the Chinese and Japanese students as nonresident and resident subjects was confirmed.

4. Evaluation result of the tourist spots According to the average evaluation score profiles, in case of the Chinese, "willingness to visit" was highly evaluated for famous tourist spots in PS, because they expected more based on a lot of information about the spots beforehand. However, in AS, "satisfaction" was evaluated lower, because they felt the spots were not as good as they had expected, when they actually visited.

5. Comparison of the psychological evaluation structure The factor analysis was applied to the image evaluation based on the Semantic Differential techniques and extracted six factors such as "Inherency", "pleasantness", "Traditionality" "Openness", "Harmony", and "Affinity". According to the result of multiple regression analysis, it can be said that the Chinese didn't have abundant knowledge about Japan and Japanese tourist spots, so they were interested in the spots with the special characteristics that they perceived simply regardless whether it is Japanese or not Japanese before visiting. However, through the visiting, they recognized more the openness of the spot and understood more the likeness of Japan, and as a result, they became to have an interest in Japanese traditional elements.

6. Conclusion The tendencies of psychological evaluation by Chinese subjects as nonresidents were characterized by comparing with that by Japanese as residents. In the future, it will be necessary to clarify the evaluation structure, such as relevance to the results of caption experiment. 